\title{
Irena Maryniakowa, Dorota K. Rembiszewska, Janusz Siatkowski Różnojęzyczne słownictwo gwarowe Podlasia, Suwalszczyzny i pótnocno-wschodniego Mazowsza Warszawa 2014, ss. 473
}

Przygotowana przez I. Maryniakową, D. Rembiszewską i J. Siatkowskiego praca Różnojęzyczne słownictwo gwarowe Podlasia, Suwalszczyzny i pótnocno-wschodniego Mazowsza jest publikacją wartościową - po raz pierwszy bowiem $\mathrm{w}$ jednej książce uwzględniono mowę i wzajemne związki wszystkich etnosów zamieszkujących przytoczony w tytule obszar. A pod względem dialektologicznym jest to region niezwykle ciekawy, gdyż spotykają się tu gwary polskie, wschodniosłowiańskie (białoruskie i ukraińskie), wielkoruskie Rosjan staroobrzędowców oraz gwary litewskie.

Koncepcja słownika gwar różnojęzycznych, którego punktem wyjścia jest przede wszystkim obszar Podlasia, zrodziła się przy okazji opracowywania kolejnych tomów leksykalnych Atlasu gwar wschodniosłowiańskich Białostocczyzny ${ }^{1}$. Autorom Różnojezzycznego słownictwa gwarowego Podlasia... przyświecała myśl, aby w jednej pracy skupić nazwy o tym samym znaczeniu z różnych systemów językowych, co miało realne uzasadnienie $\mathrm{w}$ uwarunkowaniach historycznych, geograficznych i etniczno-językowych, ale też dzięki temu będzie przydatne chociażby w dalszych badaniach dialektologicznych, czy w ogóle w badaniach z zakresu szeroko rozumianej geografii lingwistycznej.

Wstępny pomysł słownika ponad 10 lat temu w artykule Koncepcja i założenia "Stownika gwarowego Podlasia, pótnocno-wschodniego Mazowsza

1 Atlas gwar wschodniosłowiańskich Białostocczyzny, red. S. Glinka i in., t. 1-10, 1980-2009. 
i Suwalszczyzny"2 przedstawiła Irena Maryniakowa. Kiedy jednak weźmiemy do ręki już gotową pracę, okazuje się, że pewne pomysły, rozwiązania i metody zostały uzupełnione lub zmodyfikowane, co jednak wydaje się przemawiać na korzyść prezentowanej publikacji. I nie chodzi tu tylko o nieco inny niż pierwotnie tytuł pracy, ale też o zmiany w makro- i mikrostrukturze słownika, jak chociażby rezygnacja $z$ odsyłaczy w artykułach hasłowych, a w związku z tym konieczność uzupełninia książki o pokaźne (i niezwykle przydatne) indeksy.

Zasadniczą cześć prezentowanej pracy stanowi obszerny słownik. Całość została poprzedzona wstępem oraz trzyczęściowym wprowadzeniem teoretycznym. Najpierw autorzy przybliżają w krótkim zarysie historię Podlasia, Suwalszczyzny i północno-wschodniego Mazowsza. Taki komentarz wydaje się niezbędny, gdyż Podlasie to region, który na przestrzeni wieków zmieniał swoje granice, a obecne województwo podlaskie - utworzone w wyniku reformy administracyjnej z 1999 roku - wchłonęło również m.in. część północnego Mazowsza, Suwalszczyznę i Sejneńszczyznę. Wyraźnie jednak widać, że to właśnie Podlasie stanowi trzon terytorialny prezentowanej książki.

W kolejnej części przedstawione zostały kontakty językowe gwar północnego Mazowsza, Podlasia i Suwalszczyzny. Jak już wspomniano, jest to teren bardzo zróżnicowany językowo, na którym, oprócz gwar mazowieckich, pojawiają się też elementy gwar mazurskich, wschodniosłowiańskich i litewskich, czy występują obszary o przewadze gwar wschodniosłowiańskich lub litewskich. Autorzy książki zwracają uwagę (rozdział Informacje o źródłach gwarowych i gwarach na Podlasiu, Suwalszczyźnie i pótnocno-wschodnim Mazowszu), że nawet w nowszych opracowaniach naukowych wymienione gwary traktowane są - nie do końca słusznie - jako integralna część Mazowsza. Niewątpliwą zaletą charakteryzowanej pracy jest więc wydobycie i pokazanie tej leksyki, która właściwa jest Podlasiu oraz/lub przyległym mu terenom pogranicznym, różnym przecież od tzw. Mazowsza właściwego.

Ogromnym atutem publikacji Różnojęzyczne słownictwo gwarowe Podlasia... są wykorzystane materiały źródłowe. Badacze na potrzeby niniejszego słownika sięgnęli nie tylko po ogólnodostępne materiały i druko-

\footnotetext{
2 I. Maryniakowa, Koncepcja i założenia „Słownika gwarowego Podlasia, pótnocno-wschodniego Mazowsza i Suwalszczyzny, [w:] Dialektologia jako dziedzina językoznawstwa i przedmiot dydaktyki, red. S. Gala, Łódź 2002, s. 333-339.
} 
wane leksykony, ale co najważniejsze, wykorzystali słowniczki i teksty do tej pory niepublikowane (np. Słowniczek gwary podlaskiej. Powiat bielski Ryszarda Bańkowskiego czy Słownik z Wysokiego Mazowieckiego Tomasza Śmigielskiego), a także prace magisterskie z zakresu dialektologii. Co więcej, oprócz słowniczków, jako materiał źródłowy posłużyły również trzy kartoteki sporządzone przez D. Rembiszewską (z okolic Brańska, Wasilkowa oraz Wysokiego Mazowieckiego) oraz kartoteka gwary Ciechanowca i okolicznych wsi I. Maryniakowej. Ten zbierany przez wiele lat - zarówno przez doświadczone badaczki, jaki i niespecjalistów - materiał wzbogaca pracę o leksykę, która w innym przypadku nie byłaby dostępna.

Najważniejszą częścią przybliżanej pracy jest oczywiście obszerny, liczący 245 stron, słownik w układzie alfabetycznym. Hasła zostały w nim ułożone według ogólnopolskich odpowiedników gwarowych lub według definicji. Z tego też względu, aby ustrzec użytkownika przed intuicyjnym, często przypadkowym szukaniem wyrazów, pracę zaopatrzono również $w$ indeksy wyrazów. Dlatego więc na przykład wyrazów zapietek, obczas szukamy pod hasłem obcas, a formy kugiel, gugiel należy szukać pod literą $p, \mathrm{w}$ artykule hasłowym potrawa $\mathbf{z}$ krojonych ziemniaków przekładanych smażonym boczkiem i cebulą. W żaden sposób taki układ haseł nie utrudnia korzystania ze słownika, choć wymaga od użytkownika przede wszystkim dokładnego sprawdzenia wyrazów $\mathrm{w}$ indeksach.

W obrębie hasła podawane są odpowiedniki (oznaczone cyframi rzymskimi): I. polskie, II. wschodniosłowiańskie (białoruskie, ukraińskie i przejściowe białorusko-ukraińskie), III. wschodniosłowiańskie (rosyjska gwara staroobrzędowców), IV. litewskie. Co ważne, wszystkie formy notowane są ze wskazaniem źródła, co pozwala wnioskować o ich zasięgu geograficznym oraz chronologicznym (wymieniane od materiałów najstarszych do najnowszych). Dzięki zastosowaniu tej metody wiemy na przykład, że zelga 'odwilż' pojawia się w Tykocinie, Ciechanowcu i Brańsku od końca XIX do początków XXI wieku, przy czym w okolicach Tykocina notowany był właśnie pod koniec dziewiętnastego stulecia, a w Ciechanowcu i Brańsku współcześnie. Z jednej strony mamy więc słownik współczesny północno-wschodniej Polski, a z drugiej także diachroniczny. W leksykonie zastosowano również kwalifikatory chronologiczne, jednak odnoszą się one do obecnego stanu języka polskiego (daw.)ne, hist.(oryczny), przest.(arzały). 
Tam, gdzie wydało się to niezbędne, wprowadzono także kwalifikatory gramatyczne, tematyczne (bot.)aniczny, med.(yczny), rel.(igijny) czy stylistyczne (dezapr.) - z dezaprobatą, pejor.(atywny), pogard.(liwy).

Całość uzupełnia dwadzieścia pięć tablic w układzie tematycznym (np. dom, studnie i płoty, stodoła), które stanowią ilustrację wybranych desygnatów. To dość ciekawy pomysł, zwłaszcza że nie każdy użytkownik słownika może mieć specjalistyczną wiedzę z zakresu np. budowy sochy i pługa (tabl. XVIII).

Pracę zamyka przywoływany już kilka razy Indeks wyrazów gwarowych. Właściwie nie można mówić tu o jednym indeksie, bo są to cztery zestawienia - gwar polskich, gwar wschodniosłowiańskich (białoruskich i ukraińskich), gwar wielkoruskich Rosjan staroobrzędowców i ostatni gwar litewskich. Te integralne części słownika, bez których użytkownik skazany byłby na intuicyjne, często przypadkowe, a może nawet nieskuteczne poszukiwania (każdy indeks zawiera nieco inny repertuar liter), pokazują bardzo wyraźnie coś jeszcze - na opisywanym terenie gwarowym nie występuje równowaga między wschodnią a zachodnią słowiańszczyzną.

Różnojęzyczne słownictwo gwarowe Podlasia, Suwalszczyzny i pótnocno-wschodniego Mazowsza to praca bardzo ciekawa i niezwykle przydatna, zwłaszcza dla dialektologów czy historyków języka, zajmujących się polszczyzną Podlasia, Suwalszczyzny czy pogranicza mazowiecko-podlaskiego. Ponadto zebrany materiał może służyć jako pomoc dydaktyczna (również jako materiał porównawczy) na zajęciach poświęconych polszczyźnie regionalnej na kierunkach polonistycznych uczelni północno-wschodniej Polski. 